\title{
A novel 4-aminoantipyrine-Pd(II) complex catalyzes Suzuki-Miyaura cross-coupling reactions of aryl halides
}

\author{
Claudia A. Contreras-Celedón *, Darío Mendoza-Rayo, José A. Rincón-Medina \\ and Luis Chacón-García
}

\author{
Letter \\ Address: \\ Laboratorio de Síntesis y Diseño Molecular, Instituto de \\ Investigaciones Químico Biológicas, Universidad Michoacana de San \\ Nicolás de Hidalgo. Edificio B-1, Ciudad Universitaria, Morelia, \\ Michoacán, México. CP 58030, tel.: +52 443326 5790; fax: +52 443 \\ 3265788 \\ Email: \\ Claudia A. Contreras-Celedón * - celedon@umich.mx \\ ${ }^{*}$ Corresponding author \\ Keywords: \\ 4-aminoantipyrine; arylboronic acids; biaryls; cross-coupling; \\ palladium(II) complex
}

\author{
doi:10.3762/bjoc. 10.299 \\ Received: 18 September 2014 \\ Accepted: 11 November 2014 \\ Published: 01 December 2014 \\ Associate Editor: K. Itami
}

Beilstein J. Org. Chem. 2014, 10, 2821-2826.

(C) 2014 Contreras-Celedón et al; licensee Beilstein-Institut. License and terms: see end of document.

\begin{abstract}
A simple and efficient catalytic system based on a Pd complex of 4-aminoantipyrine, 4-AAP-Pd(II), was found to be highly active for Suzuki-Miyaura cross-coupling of aryl iodides and bromides with phenylboronic acids under mild reaction conditions. Good to excellent product yields from the cross-coupling reaction can be achieved when the reaction is carried out in ethanol, in the open air, using low loading of 4-AAP-Pd(II) as a precatalyst, and in the presence of aqueous $\mathrm{K}_{2} \mathrm{CO}_{3}$ as the base. A variety of functional groups are tolerated.
\end{abstract}

\section{Introduction}

The $\mathrm{sp}^{2}-\mathrm{sp}^{2}$ carbon-carbon bond formation through crosscoupling reactions catalyzed by metal complexes has emerged as a powerful tool in organic synthesis [1-6]. The palladiumcatalyzed cross-coupling of arylboronic acid and aryl halides in the Suzuki-Miyaura (SM) reaction is one of the most popular and important methods to obtain biaryls, which are essential structures of many important compounds such as natural products [7], agrochemicals [8], pharmaceuticals [9] and polymers [10] among others. The broad application of the SM coupling arises from the exceptionally mild reaction conditions, the toler- ance to different functional groups, the relatively stable, readily prepared and generally environmentally benign nature of the oroganoboron reagents, and their rapid transmetalation with palladium(II) complexes [11].

Although in recent years there have been numerous studies on the SM cross-coupling reaction, the necessity for a simple procedure that allows the formation of $\mathrm{C}-\mathrm{C}$ bonds in functionalized substrates remains. There have been ongoing efforts to develop a stable and efficient Pd catalyst for these reactions. 
Recently, palladium complexes containing imidazole-imines [12], binary nanoclusters [13], N-heterocyclic carbenes (NHCs) [14], nanoparticles [15], palladacycles [16], and Schiff bases [17] have been developed as highly effective phosphine-free catalysts for SM coupling reactions.

Transition metal complexes that have shown a wide range of biological activity are those containing the pyrazolone derivative 4-aminoantipyrine (4-amino-1,5-dimethyl-2-phenyl-1Hpyrazol-3(2H)-one, or simply "4-AAP") [18]. Pyrazoles, in general, are one of the most important classes of bioactive heterocycles, having attracted increasing interest to the pharmaceutical, chemical and agricultural industries over the past decade, and in recent years a number of research articles have been published specifically about 4-AAP [19]. Analogues and transition metal complexes of 4-AAP have shown anti-inflammatory, analgesic, antiviral, antipyretic, antirheumatic and antimicrobial activity [20,21]. Despite the potential biological importance of 4-AAP, the catalytic activity of its transition metal complexes for $\mathrm{C}-\mathrm{C}$ bond formation have not yet been investigated. Herein, we report the synthesis of the new 4-aminoantipyrine-Pd(II) complex [4-AAP-Pd(II)] by mixing $\mathrm{Li}_{2} \mathrm{PdCl}_{4}, 4$-aminoantipyrine in presence of $\mathrm{NaOAc}$ in $\mathrm{MeOH}$ at room temperature, and its performance as catalysts in SM crosscoupling reaction of structurally different aryl halides with phenylboronic acids. The biaryls are obtained in moderate to high yield.

\section{Results and Discussion}

The synthesis of the 4-APP-Pd(II) complex was carried out using a convenient one-pot procedure, as reported in the literature for other ligands [22], by combining $\mathrm{Li}_{2} \mathrm{PdCl}_{4}, 4$-AAP and $\mathrm{NaOAc}$ in methanol at room temperature (Scheme 1).

The 4-AAP-Pd(II) complex is thermally stable, not sensitive to oxygen or moisture, and highly soluble in common solvents such as $\mathrm{CHCl}_{3}, \mathrm{CH}_{2} \mathrm{Cl}_{2}$ and AcOEt. The newly synthesized 4-AAP-Pd(II) complex was characterized by UV-vis, FTIR,

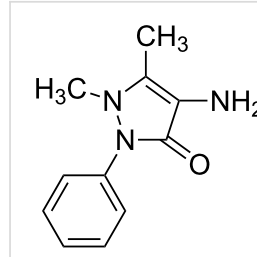

4-APP

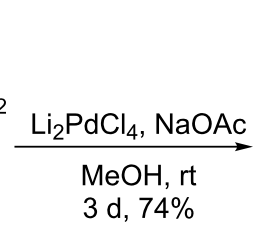

$3 \mathrm{~d}, 74 \%$

\section{cheme 1: Synthesis of 4-aminoantipyrine-Pd(II) complex.}

${ }^{1} \mathrm{H},{ }^{13} \mathrm{C}$ NMR spectroscopy and MS (Table 1). The UV-vis spectra in $\mathrm{CH}_{3} \mathrm{CN}$ showed a broad band at approximately $465 \mathrm{~nm}$. In the IR spectra, the characteristic $\mathrm{NH}$ and $\mathrm{C}=\mathrm{O}$ stretching absorption bands appeared around 3476 and $1616 \mathrm{~cm}^{-1}$, respectively. Anal. calcd for $\mathrm{C}_{22} \mathrm{H}_{24} \mathrm{Cl}_{2} \mathrm{~N}_{6} \mathrm{O}_{2} \mathrm{Pd}_{2}$ C 38.39, H 3.51, N 12.21; found: C 38.52, H 3.54, N 12.35. The ${ }^{1} \mathrm{H}$ NMR spectra showed signals at 7.55-7.44 and 7.33-7.42 ppm, integrating for five aromatics protons. The signals for the $\mathrm{N}-\mathrm{CH}_{3}$ and the $\mathrm{C}-\mathrm{CH}_{3}$ protons were shifted upfield from their positions in uncomplexed 4-AAP, being observed as singlets at 3.07 and $2.29 \mathrm{ppm}$ respectively. The $\mathrm{NH}$ signal was similarly shifted upfield, to $1.84 \mathrm{ppm}$, with its integration indicating one proton. This result suggests to us that the palladium interacts with the carbonyl and amine groups of the pyrazole ring of 4-AAP.

The synthesized 4-AAP-Pd(II) complex was used to carry out all palladium-catalyzed Suzuki-Miyaura cross-coupling reactions described in this report. We screened various solvents, bases, and percents of precatalyst loaded, in order to optimize the reactions conditions, and then applied these optimized conditions to reactions on a wide scope of substrates. For each of the three screening experiments, phenylboronic acid (1a) and $p$-bromobenzaldehyde (2e) were chosen as the model substrates, which in the coupling reaction produced the biphenyl 3q (see Table 2 and Table 3). We first describe the results of these screens. The screen for solvents was carried out using $0.3 \mathrm{~mol} \%$ of the palladium complex as a catalyst and many

Table 1: Spectroscopic data for 4-AAP and 4-APP-Pd(II) complex

\begin{tabular}{|c|c|c|}
\hline & Compound & Signals \\
\hline \multirow[t]{2}{*}{ IR } & 4-AAP & $3432,3325\left(\mathrm{NH}_{2}\right), 3246\left(\mathrm{~N}-\mathrm{CH}_{3}\right), 2914(\mathrm{CH}-\mathrm{Ar}), 1643(\mathrm{C}=\mathrm{O})$ \\
\hline & 4-APP-Pd(II) & $3474(\mathrm{NH}), 2924(\mathrm{CH}-\mathrm{Ar}), 1616(\mathrm{C}=\mathrm{O})$ \\
\hline \multirow{2}{*}{$\begin{array}{l}{ }^{1} \mathrm{H} \mathrm{NMR} \\
\left(\mathrm{CDCl}_{3}\right)\end{array}$} & 4-AAP & 7.5-7.4 (2H-Ar), 7.3-7.2 (3H-Ar), $2.95\left(2 \mathrm{H}, \mathrm{NH}_{2}\right), 2.84\left(3 \mathrm{H}, \mathrm{N}-\mathrm{CH}_{3}\right), 2.15\left(3 \mathrm{H}, \mathrm{C}-\mathrm{CH}_{3}\right)$ \\
\hline & 4-APP-Pd(II) & 7.55-7.44 (2H-Ar), 7.42-7.33 (3H-Ar), $1.84(1 \mathrm{H}, \mathrm{NH}), 3.07\left(3 \mathrm{H}, \mathrm{N}-\mathrm{CH}_{3}\right), 2.29\left(3 \mathrm{H}, \mathrm{C}-\mathrm{CH}_{3}\right)$ \\
\hline \multirow[t]{2}{*}{$\begin{array}{l}{ }^{13} \mathrm{C} \mathrm{NMR} \\
\left(\mathrm{CDCl}_{3}\right)\end{array}$} & 4-AAP & $\begin{array}{l}162.0(\mathrm{C}=\mathrm{O}), 138.0,118.9(\mathrm{~N}-\mathrm{C}=\mathrm{C}), 135.3,128.9,125.8,122.7(\mathrm{C}-\mathrm{Ar}), 37.8\left(\mathrm{~N}-\mathrm{CH}_{3}\right), 10.1 \\
\left(\mathrm{C}-\mathrm{CH}_{3}\right)\end{array}$ \\
\hline & 4-APP-Pd(II) & $\begin{array}{l}161.4(\mathrm{C}=\mathrm{O}), 133.2,112.3(\mathrm{~N}-\mathrm{C}=\mathrm{C}), 143.7,129.3,129.0,127.8,124.7,123.3(\mathrm{C}-\mathrm{Ar}), 35.4 \\
\left(\mathrm{~N}-\mathrm{CH}_{3}\right), 10.3\left(\mathrm{C}-\mathrm{CH}_{3}\right)\end{array}$ \\
\hline
\end{tabular}


Table 2: Screening of solvent and base for the 4-AAP-Pd(II)-catalyzed cross-coupling reaction. ${ }^{\text {a }}$<smiles>Oc1ccccc1</smiles>

$1 \mathrm{a}$<smiles>O=Cc1ccc(Br)cc1</smiles>

$2 \mathrm{e}$<smiles>O=Cc1ccc(-c2ccccc2)cc1</smiles>

$3 q$

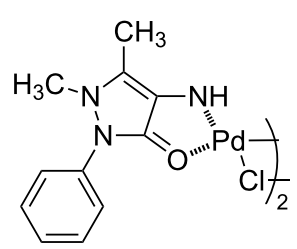

4-APP-Pd(II)

\begin{tabular}{|c|c|c|c|c|}
\hline Entry & Solvent & Base & Time $(h)$ & $3 q$ yield $(\%)^{b}$ \\
\hline 1 & $\mathrm{H}_{2} \mathrm{O}$ & $\mathrm{Na}_{2} \mathrm{CO}_{3}$ & 4 & 47 \\
\hline 2 & THF & $\mathrm{Na}_{2} \mathrm{CO}_{3}$ & 8 & 29 \\
\hline 3 & $\mathrm{DMF}^{\mathrm{C}}$ & $\mathrm{Na}_{2} \mathrm{CO}_{3}$ & 3 & 37 \\
\hline 4 & toluene $e^{c}$ & $\mathrm{Na}_{2} \mathrm{CO}_{3}$ & 3 & 36 \\
\hline 5 & benzene & $\mathrm{Na}_{2} \mathrm{CO}_{3}$ & 8 & 67 \\
\hline 6 & PEG $600^{c}$ & $\mathrm{Na}_{2} \mathrm{CO}_{3}$ & 4 & 30 \\
\hline 7 & PEG $600 / \mathrm{H}_{2} \mathrm{O}(1: 1.5)^{\mathrm{C}}$ & $\mathrm{Na}_{2} \mathrm{CO}_{3}$ & 4 & 33 \\
\hline 8 & $\mathrm{MeOH}$ & $\mathrm{Na}_{2} \mathrm{CO}_{3}$ & 3 & 75 \\
\hline 9 & $\mathrm{EtOH}$ & $\mathrm{Na}_{2} \mathrm{CO}_{3}$ & 4 & 89 \\
\hline 10 & $\mathrm{EtOH}^{\mathrm{d}}$ & $\mathrm{Na}_{2} \mathrm{CO}_{3}$ & 22 & 88 \\
\hline 11 & $\mathrm{EtOH} / \mathrm{H}_{2} \mathrm{O}(1: 1)$ & $\mathrm{Na}_{2} \mathrm{CO}_{3}$ & 3 & 69 \\
\hline 12 & $\mathrm{EtOH} / \mathrm{H}_{2} \mathrm{O}(1: 1)$ & $\mathrm{Na}_{2} \mathrm{CO}_{3}$ & 22 & 57 \\
\hline 13 & $\mathrm{EtOH}^{\mathrm{a}, \mathrm{d}}$ & - & 24 & - \\
\hline 14 & $\mathrm{EtOH}$ & $\mathrm{NaOH}$ & 4 & 17 \\
\hline 15 & $\mathrm{EtOH}$ & $\mathrm{NaOAC}$ & 4 & 59 \\
\hline 16 & $\mathrm{EtOH}$ & $\mathrm{K}_{3} \mathrm{PO}_{4}$ & 4 & 68 \\
\hline 17 & $\mathrm{EtOH}$ & $\mathrm{K}_{2} \mathrm{CO}_{3}$ & 4 & 89 \\
\hline 18 & $\mathrm{EtOH}^{\mathrm{a}, \mathrm{c}, \mathrm{e}}$ & $\mathrm{K}_{2} \mathrm{CO}_{3}$ & 24 & - \\
\hline
\end{tabular}

aReaction conditions: phenylboronic acid (1a, $0.40 \mathrm{mmol}), p$-bromobenzaldehyde (2e, $0.27 \mathrm{mmol}), 4-\mathrm{AAP}-\mathrm{Pd}(\mathrm{II})(0.3 \mathrm{~mol} \%), 2 \mathrm{M}$ base (0.67 mmol) and solvent $(2 \mathrm{~mL})$ at reflux. ${ }^{\mathrm{b}}$ Isolated yield. ${ }^{\mathrm{c}}$ The reaction was carried out at $80^{\circ} \mathrm{C}$. ${ }^{\mathrm{d}}$ The reaction was carried out at room temperature. ${ }^{\mathrm{e}}$ The reaction was carried out in the presence of $\mathrm{Li}_{2} \mathrm{PdCl}_{4}$ as catalyst.

bases; the results are summarized in Table 2. The reaction proceeded in both protic and aprotic solvents, but with significantly varying yields of the product. In the cases of $\mathrm{H}_{2} \mathrm{O}$, THF, DMF, toluene, benzene and PEG 600 solvents, the yields were between $29-67 \%$ (Table 2, entries 1-6), all lower than the product yield obtained when using methanol or ethanol as the solvent (Table 2, entries 8-10). In the case of ethanol (Table 2, entries 9 and 10) the percent yield of product $\mathbf{3 q}$ was relatively high $(89 \%)$ when the reaction was carried out with heating under reflux for 4 hours, but was also similarly high when the reaction was carried out at room temperature for 22 hours. However, the yield of $\mathbf{3 q}$ was low when 1:1.5 PEG $600 / \mathrm{H}_{2} \mathrm{O}$ was used at $80{ }^{\circ} \mathrm{C}$ (Table 2, entry 7) and moderate yield when 1:1 EtOH $/ \mathrm{H}_{2} \mathrm{O}$ when was used as solvent at room temperature (rt) or at $80{ }^{\circ} \mathrm{C}$ (Table 2, entries 11 and 12). Different bases were screened using $0.3 \mathrm{~mol} \%$ of the 4-AAP-Pd(II) complex in ethanol at reflux (Table 2). When the reaction (Table 2, entry 13) was conducted without any base, no reaction was observed even after $24 \mathrm{~h}$ at room temperature or reflux. In the case of $\mathrm{NaOH}$ (Table 2, entry 14) we observed a poor product yield (17\%). In the presence of bases, such as $\mathrm{NaOAc}$ and $\mathrm{K}_{3} \mathrm{PO}_{4}$, moderate yields are obtained (Table 2, entries 15 and 16). $\mathrm{Na}_{2} \mathrm{CO}_{3}$ and $\mathrm{K}_{2} \mathrm{CO}_{3}$ were found to give the best yields (Table 2, entries 9 and 17). In entry 18, the reaction was carried out in the presence of $\mathrm{Li}_{2} \mathrm{PdCl}_{4}$ as catalyst and no reaction was observed even after $24 \mathrm{~h}$ at room temperature or reflux. The results shown in Table 2 indicate that aqueous $\mathrm{K}_{2} \mathrm{CO}_{3}$ or $\mathrm{Na}_{2} \mathrm{CO}_{3}$ as base and ethanol as solvent are the best conditions of those tested for the 4-AAP-Pd(II)-catalyzed cross-coupling reaction of phenylboronic acid (1a) with $p$-bromobenzaldehyde (2e).

For the final screen, catalyst loading tests, at various relatively low levels of 4-AAP-Pd(II), were performed to determine its catalytic efficiency. This screen was carried out in the presence of aqueous $\mathrm{K}_{2} \mathrm{CO}_{3}$ as base and ethanol as solvent. Decreasing 
Table 3: Effect of low precatalyst loading. ${ }^{\text {a }}$<smiles>Oc1ccccc1</smiles>

$1 a$<smiles>O=Cc1ccc(Br)cc1</smiles>

$2 \mathrm{e}$<smiles>O=Cc1ccc(-c2ccccc2)cc1</smiles>

$3 q$

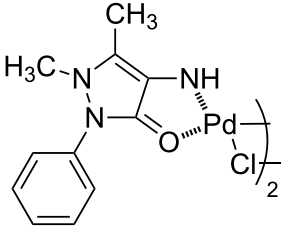

4-APP-Pd(II)

\begin{tabular}{lllll}
\hline Entry & precatalyst $(\mathrm{mol} \% \mathrm{Pd})$ & Time $(\mathrm{h})$ & 3q Yield $(\%)^{\mathrm{b}}$ & TON $^{\mathrm{d}}$ \\
\hline 1 & 0.03 & 4 & 46 & 3059 \\
2 & $0.03^{\mathrm{C}}$ & 22 & 88 & 5852 \\
3 & 0.3 & 4 & 89 & 591 \\
4 & $0.3^{\mathrm{C}}$ & 22 & 88 & 585 \\
5 & 3 & 4 & 82 & 55 \\
6 & $3^{\mathrm{c}}$ & 22 & 71 & 47 \\
\hline
\end{tabular}

${ }^{a}$ Reaction conditions: phenylboronic acid (1a, $\left.0.40 \mathrm{mmol}\right), p$-bromobenzaldehyde $(2 \mathrm{e}, 0.27 \mathrm{mmol}), 4-\mathrm{AAP}-\mathrm{Pd}(\mathrm{II}), 2 \mathrm{M} \mathrm{K} \mathrm{CO}_{3},(0.067 \mathrm{mmol})$, ethanol $(2 \mathrm{~mL})$ heating under reflux. ${ }^{\mathrm{b}}$ Isolated yield. ${ }^{\mathrm{C}}$ The reaction was carried out at room temperature. ${ }^{\mathrm{d}} \mathrm{TON}=$ mol of product per mol of catalyst.

the concentration of catalyst from $0.3 \mathrm{~mol} \%$ to $0.03 \mathrm{~mol} \%$ substantially reduced the product yield (to $46 \%$, see Table 3 entry 1 ) when the reaction was carried out under reflux for $4 \mathrm{~h}$, but did not reduce the yield when the reaction was carried out at room temperature for $22 \mathrm{~h}$ (Table 3, entry 2). However, when using only $0.3 \mathrm{~mol} \%$ of 4 -AAP-Pd(II), the reaction proceeded with relatively high yield of product (88-89\%) when carried out for up to $4 \mathrm{~h}$ with heating at reflux or at room temperature for $22 \mathrm{~h}$ (Table 3, entries 3 and 4). Increasing the concentration of catalyst, from $0.3 \mathrm{~mol} \%$ to $3 \mathrm{~mol} \%$ somewhat reduced the product yield, to moderate levels, when the reaction was carried out at either room temperature for $22 \mathrm{~h}$ or under reflux for $4 \mathrm{~h}$ (Table 3, entries 5 and 6). The decrease in the coupling yield at high concentrations of $\mathrm{Pd}(\mathrm{II})$ catalyst is a common phenomenon in palladium chemistry due to the aggregation of $\operatorname{Pd}(0)$ occurs $[3,23]$.

In order to explore the scope of the SM cross-coupling reaction using the 4-AAP-Pd(II) complex, we examined the reactions of a wide array of electronically diverse aryl iodides and bromides with electron-withdrawing or electron-donating substituents on the phenylboronic acids. The effects of the substituents of the arylboronic acid on the product yield of this reaction have been analyzed. Of particular note is our observation that many products could be isolated without the need for column chromatography. Using this protocol, all 8 tested reactions of phenylboronic acids $\mathbf{1 a}-\mathbf{1 d}$ with phenyl iodides $\mathbf{2 a}, \mathbf{2 b}$ proceeded smoothly to produce the desired biphenyl compounds in high to excellent yields (91-99\%) (Scheme 2, compounds 3a-3h). The 16 reactions with aryl bromides $\mathbf{2 c}-\mathbf{2 f}$ also proceeded well and afforded the corresponding biphenyl products (Scheme 2 compounds 3i-3x) in moderate to high yields (61-98\%). The catalytic system was tolerant for both electron-donating and electron-withdrawing substituents; our protocol successfully accommodated the free hydroxy and amino groups as substituents on the aryl iodides and bromides without additional protection procedures, and the reactions with these substrates produced the corresponding biphenyl compounds with moderate yields (Scheme 2 compounds $\mathbf{3 e}-\mathbf{3 h}, \mathbf{3 m} \mathbf{- 3} \mathbf{p}$, 3u-3x). In addition to the yield, the turnover number (TON in Scheme 2) of the 4-AAP-Pd(II) catalyst was measured, and found to be moderate (400-700) for all 24 tested cross-coupling reactions, suggesting that the catalyst is also efficient.

\section{Conclusion}

In summary, we have developed a mild, efficient and comparatively inexpensive methodology for the synthesis of biaryl compounds. This methodology uses our newly developed 4-AAP-Pd(II) complex as a highly efficient precatalyst and general catalyst for the SM cross-coupling, works without the necessity of phosphine ligands, and was also found to be active for the cross-coupling of aryl iodides and bromides with substituted phenylboronic acids. The SM cross-coupling reaction can be carried out in $\mathrm{EtOH}$, in the presence of air, with low catalyst loadings, and heating at reflux conditions for relatively short reaction times to afford biaryl compounds in good to excellent yields. The synthetic accessibility and stability under crosscoupling reaction conditions of 4-AAP-Pd(II) make this complex a very promising precatalyst, and we will continue studying its applicability in various organic reactions. 


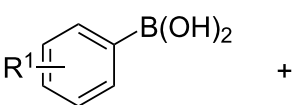<smiles>[R]c1cc[Y]cc1</smiles>

4-AAP-Pd(II)

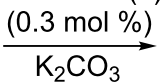
EtOH, reflux
1a, $\mathrm{R}^{1}=\mathrm{H}$
1b, $\mathrm{R}^{1}=p-\mathrm{OCH}_{3}$
1c, $\mathrm{R}^{1}=p-\mathrm{CF}_{3}$
1d, $\mathrm{R}^{1}=m-\mathrm{NO}_{2}$

2a, $\mathrm{R}^{2}=\mathrm{H}, \mathrm{X}=\mathrm{I}$

2b, $\mathrm{R}^{2}=\mathrm{CH}_{2} \mathrm{OH}, X=0-\mathrm{I}$

2c, $\mathrm{R}^{2}=\mathrm{NO}_{2}, \mathrm{X}=p-\mathrm{Br}$

2d, $\mathrm{R}^{2}=\mathrm{OH}, \mathrm{X}=0-\mathrm{Br}$

2e, $\mathrm{R}^{2}=\mathrm{CHO}, \mathrm{X}=p-\mathrm{Br}$

2f, $\mathrm{R}^{2}=\mathrm{NH}_{2}, \mathrm{X}=p-\mathrm{Br}$<smiles>[R]c1cccc(-c2cc[R1]cc2)c1</smiles>

$3 a-3 x^{a, b}$<smiles>CCC[PH]1(C)(CC)=C2C(=C(C)N(C)N2c2ccccc2)N1</smiles>

4-APP-Pd(II)<smiles>[R11]1ccc(-c2ccccc2)cc1</smiles><smiles>OCc1ccccc1-c1cc[R1]cc1</smiles><smiles>O=[N+]([O-])c1ccc(-c2cc[R1]cc2)cc1</smiles>

3a, $\mathrm{R}^{1}=\mathrm{H}, 99 \%$, TON $=659$

3e, $\mathrm{R}^{1}=\mathrm{H}, 95 \%$, TON $=632$

3i, $\mathrm{R}^{1}=\mathrm{H}, 86 \%$, TON $=572$

3b, $\mathrm{R}^{1}=p-\mathrm{OCH}_{3}, 95 \%$, TON $=631$

3f, $\mathrm{R}^{1}=p-\mathrm{OCH}_{3}, 91 \%, \mathrm{TON}=605$

3j, $\mathrm{R}^{1}=p-\mathrm{OCH}_{3}, 87 \%$, TON $=57 \mathrm{c}$

3c, $\mathrm{R}^{1}=p-\mathrm{CF}_{3}, 99 \%$, TON $=659$

$3 \mathbf{g}, \mathrm{R}^{1}=p-\mathrm{CF}_{3}, 99 \%$, TON $=659$

$3 \mathbf{k}, \mathrm{R}^{1}=p-\mathrm{CF}_{3}, 92 \%$, TON $=612$

3d, $\mathrm{R}^{1}=m-\mathrm{NO}_{2}, 99 \%$, TON $=659$

$3 \mathbf{h}, \mathrm{R}^{1}=m-\mathrm{NO}_{2}, 99 \%$, TON $=659$

3I, $\mathrm{R}^{1}=m-\mathrm{NO}_{2}, 61 \%, \mathrm{TON}=406$<smiles>Oc1ccccc1-c1cc[R1]cc1</smiles><smiles>O=Cc1ccc(-c2cc[R1]cc2)cc1</smiles>

3q, $\mathrm{R}^{1}=\mathrm{H}, 89 \%$, TON $=592$

$3 \mathbf{r}, \mathrm{R}^{1}=p-\mathrm{OCH}_{3}, 98 \%$, TON $=652$

3u, $\mathrm{R}^{1}=\mathrm{H}, 87 \%$, TON $=579$

$3 \mathrm{~m}, \mathrm{R}^{1}=\mathrm{H}, 84 \%$, TON $=559$

3s, $\mathrm{R}^{1}=p-\mathrm{CF}_{3}, 86 \%$, TON $=572$

3o, $\mathrm{R}^{1}=p-\mathrm{CF}_{3}, 70 \%$, TON $=466$

3p, $\mathrm{R}^{1}=m-\mathrm{NO}_{2}, 69 \%, \mathrm{TON}=459$<smiles></smiles>

Scheme 2: Reaction of different aryl halides with substituted arylboronic acids. Reaction conditions: phenylboronic acid $(0.40 \mathrm{mmol})$, aryl halide $(0.27$ mmol), 4-AAP-Pd(II) $(0.3 \mathrm{~mol} \%), 2 \mathrm{M} \mathrm{K}_{2} \mathrm{CO}_{3}(0.67 \mathrm{mmol})$, ethanol $(2 \mathrm{~mL})$, heating under reflux for $4 \mathrm{~h}$. ${ }^{\text {al }}$ lsolated yield. ${ }^{\mathrm{b}} \mathrm{TON}=$ mol of product per mol of catalyst.

\section{Supporting Information}

\section{Supporting Information File 1}

Full experimental details and copies of all NMR spectra

$\left({ }^{1} \mathrm{H}\right.$ and ${ }^{13} \mathrm{C}$ spectra) of all compounds isolated.

[http://www.beilstein-journals.org/bjoc/content/

supplementary/1860-5397-10-299-S1.pdf]

\section{Acknowledgements}

We are grateful to the CIC-UMSNH for financial support of this work.

\section{References}

1. Suzuki, A. Acc. Chem. Res. 1982, 15, 178-184. doi:10.1021/ar00078a003

2. Hassan, J.; Sévignon, M.; Gozzi, C.; Schulz, E.; Lemaire, M. Chem. Rev. 2002, 102, 1359-1470. doi:10.1021/cr000664r

3. Phan, N. T. S.; Van Der Sluys, M.; Jones, C. W. Adv. Synth. Catal. 2006, 348, 609-679. doi:10.1002/adsc.200505473

4. Alonso, F.; Beletskaya, I. P.; Yus, M. Tetrahedron 2008, 64, 3047-3101. doi:10.1016/j.tet.2007.12.036

5. Fihri, A.; Bouhrara, M.; Nekoueishahraki, B.; Basset, J.-M.; Polshettiwar, V. Chem. Soc. Rev. 2011, 40, 5181-5203. doi:10.1039/c1cs15079k 
6. Han, F.-S. Chem. Soc. Rev. 2013, 42, 5270-5298. doi:10.1039/c3cs35521g

7. Aldemir, H.; Richarz, R.; Gulder, T. A. M. Angew. Chem., Int. Ed. 2014, 53, 8286-8293. doi:10.1002/anie.201401075

8. Chi, H.; Cui, D.; Liu, C.; Ma, H.; Wang, L.; Wang, Z.; Wu, Q.; Zhang, J. Substituted biaryl benzenesulfonamide compound and use. PCT Int. Appl. WO2012059050 A1, May 10, 2012.

9. Doucet, H.; Hierso, J.-C. Curr. Opin. Drug Discovery Dev. 2007, 10, 672-690.

10. Nagamani, C.; Guo, J.; Thayumanavan, S. J. Polym. Sci., Part A: Polym. Chem. 2012, 50, 1187-1196. doi:10.1002/pola. 25880

11. Lennox, A. J. J.; Lloyd-Jones, G. C. Chem. Soc. Rev. 2014, 43, 412-443. doi:10.1039/c3cs60197h

12. Ratniyom, J.; Chaiprasert, T.; Pramjit, S.; Yotphan, S.; Sangtrirutnugul, P.; Srisuratsiri, P.; Kongsaeree, P.; Kiatisevi, S. J. Organomet. Chem. 2014, 752, 161-170. doi:10.1016/j.jorganchem.2013.12.015

13. Seth, K.; Purohit, P.; Chakraborti, A. K. Org. Lett. 2014, 16, 2334-2337. doi:10.1021/ol500587m

14. Meiries, S.; Le Duc, G.; Chartoire, A.; Collado, A.; Speck, K.; Athukorala Arachchige, K. S.; Slawin, A. M. Z.; Nolan, S. P. Chem. - Eur. J. 2013, 19, 17358-17368. doi:10.1002/chem.201302471

15. Isfahani, A. L.; Mohammadpoor-Baltork, I.; Mirkhani, V.; Khosropour, A. R.; Moghadam, M.; Tangestaninejad, S.; Kia, R. Adv. Synth. Catal. 2013, 355, 957-972. doi:10.1002/adsc.201200707

16. Cívicos, J. F.; Alonso, D. A.; Nájera, C. Adv. Synth. Catal. 2011, 353, 1683-1687. doi:10.1002/adsc.201100019

17. Shahnaz, N.; Banik, B.; Das, P. Tetrahedron Lett. 2013, 54, 2886-2889. doi:10.1016/j.tetlet.2013.03.115

18. Kalanithi, M.; Rajarajan, M.; Tharmaraj, P. J. Coord. Chem. 2011, 64, 1436-1445. doi:10.1080/00958972.2011.572965

19. Costa, D.; Marques, A. P.; Reis, R. L.; Lima, J. L. F. C.; Fernandes, E. Free Radical Biol. Med. 2006, 40, 632-640. doi:10.1016/j.freeradbiomed.2005.09.017

20. Burdulene, D.; Palaima, A.; Stumbryavichyute, Z.; Talaikite, Z. Pharm. Chem. J. 1999, 33, 191-193. doi:10.1007/BF02509936

21. Alam, M. S.; Choi, J.-H.; Lee, D.-U. Bioorg. Med. Chem. 2012, 20 , 4103-4108. doi:10.1016/j.bmc.2012.04.058

22. Onoue, H.; Minami, K.; Nakagawa, K. Bull. Chem. Soc. Jpn. 1970, 43, 3480-3485. doi:10.1246/bcsj.43.3480

23. Kumar, A.; Rao, G. K.; Kumar, S.; Singh, A. K. Organometallics 2014, 33, 2921-2943. doi:10.1021/om4007196

\section{License and Terms}

This is an Open Access article under the terms of the Creative Commons Attribution License

(http://creativecommons.org/licenses/by/2.0), which permits unrestricted use, distribution, and reproduction in any medium, provided the original work is properly cited.

The license is subject to the Beilstein Journal of Organic Chemistry terms and conditions:

(http://www.beilstein-journals.org/bjoc)

The definitive version of this article is the electronic one which can be found at:

doi:10.3762/bjoc. 10.299 